

\title{
Latest Danian carbon isotope anomaly and associated environmental change in the southern Tethys (Nile Basin, Egypt)
}

\author{
ANDRÉ BORNEMANN ${ }^{1 *}$, PETER SCHULTE ${ }^{2}$, JORINDE SPRONG ${ }^{3}$, ETIENNE STEURBAUT ${ }^{3,4}$, \\ MOHAMED YOUSSEF ${ }^{5} \&$ ROBERT P. SPEIJER ${ }^{3}$ \\ ${ }^{1}$ Institut für Geophysik und Geologie, Universität Leipzig, Talstraße 35, D-04103 Leipzig, Germany \\ ${ }^{2}$ GeoZentrum Nordbayern, Universität Erlangen-Nürnberg, Schlossgarten 5, D-91054 Erlangen, Germany \\ ${ }^{3}$ Department of Earth and Environmental Sciences, K.U.Leuven, Celestijnenlaan 200E, B-3001 Leuven, Belgium \\ ${ }^{4}$ Royal Belgian Institute of Natural Sciences, Vautierstraat 29, B-1000 Brussels, Belgium \\ ${ }^{5}$ Geology Department, Faculty of Science, South Valley University, 83523 Qena, Egypt \\ *Corresponding author (e-mail: a.bornemann@uni-leipzig.de)
}

\begin{abstract}
During the Palaeocene and Eocene Epochs (65.5-33.9 Ma) the Earth experienced the warmest conditions of the Cenozoic. This Palaeogene greenhouse episode is characterized by several short-lived negative carbon isotope $\left({ }^{13} \mathrm{C}\right)$ excursions, which are usually interpreted as transient warming events ('hyperthermals') as indicated by rising temperatures of surface and bottom waters, and accompanied carbonate dissolution in deep-sea settings. Among these events, the Palaeocene-Eocene Thermal Maximum (PETM, c. $55.5 \mathrm{Ma}$ ) is globally the best documented and most prominent. Further negative $\delta^{13} \mathrm{C}$ anomalies have recently been identified in the Eocene, but the early to middle Palaeocene has mostly been neglected. Here, benthic foraminiferal $\delta^{13} \mathrm{C}$ records are presented from four upper Danian-lower Selandian sections in the Nile Basin (eastern Egypt). All records show a negative $\delta^{13} \mathrm{C}$ shift with an amplitude of up to $2 \%$ at the base of planktonic foraminiferal subzone P3b (c. 61 Ma). The supra-regional nature of this event is emphasized by correlation with a well-dated, similar $\delta^{13} \mathrm{C}$ record from Zumaia (Spain). Lithological changes, the $\delta^{13} \mathrm{C}$ signature and biotic responses strongly resemble those of the PETM in Egypt, which leads to the hypothesis that this 'Latest Danian Event' (LDE) may represent another early Palaeocene hyperthermal.
\end{abstract}

Several negative carbon isotope $\left(\delta^{13} \mathrm{C}\right)$ excursions $(>0.5 \%)$ have been identified during the Palaeogene greenhouse episode (e.g. Kennett \& Stott 1991; Cramer et al. 2003; Lourens et al. 2005; Nicolo et al. 2007; Quillévéré et al. 2008). The most prominent, and probably most severe one is the Palaeocene-Eocene Thermal Maximum (PETM) at c. $55.5 \mathrm{Ma}$, which shows a rapid $\delta^{13} \mathrm{C}$ decrease of $>2.5 \%$ and lasted for about 170-220 ka (Kennett \& Stott 1991; Bralower et al. 1995; Röhl et al. 2000, 2007; Zachos et al. 2001, 2006). This negative $\delta^{13} \mathrm{C}$ shift coincides with decreasing $\delta^{18} \mathrm{O}$ values of foraminiferal shells, which reflect short-lived hyperthermal conditions indicating a warming of bottom and surface waters of up to $10{ }^{\circ} \mathrm{C}$ (Kennett \& Stott 1991; Zachos et al. 2003, 2006; Tripati \& Elderfield 2005).

To explain the observed negative carbon isotope excursions, it has been postulated (e.g. Dickens et al. 1997) that isotopically light carbon was added to the ocean and atmosphere system, perturbing the carbon cycle as reflected in negative $\delta^{13} \mathrm{C}$ values of marine and terrestrial carbonates, and organic matter (e.g. Kennett \& Stott 1991; Bowen et al. 2004; Pagani et al. 2006a; Yans et al. 2006). These carbon isotope excursions are usually ascribed to the release of ${ }^{12} \mathrm{C}$-enriched methane from the sea floor, which oxidized rapidly to produce $\mathrm{CO}_{2}$ (Dickens et al. 1997). The input of huge amounts of $\mathrm{CO}_{2}$ into the ocean-atmosphere system increased global temperature, accelerated the hydrological and weathering cycle, and induced a substantial shoaling of the ocean lysocline and the calcite compensation depth (e.g. Dickens et al. 1997; Ravizza et al. 2001; Schmitz et al. 2001; Bowen et al. 2004; Zachos et al. 2005). However, reliable quantification of the amount of released $\mathrm{CO}_{2}$ and its source is still under discussion (Higgins \& Schrag 2006; Pagani et al. 2006b).
Further, less pronounced negative $\delta^{13} \mathrm{C}$ inflections have been identified in the Eocene (Bralower et al. 2002; Cramer et al. 2003; Lourens et al. 2005; Nicolo et al. 2007). Also, for the Palaeocene several less well-documented candidates for transient warming events have been proposed (Thomas \& Zachos 2000), which include: (1) the early Danian Dan-C2 event (c. 65.2 Ma; Quillévéré et al. 2008); (2) the Danian-Selandian (D-S) transition (c. $61 \mathrm{Ma}$; Speijer 2003); (3) the mid-Palaeocene biotic event (c. 58.2 Ma; Bralower et al. 2002; Petrizzo 2005; Bernaola et al. 2007). To date, evidence for ocean warming in addition to a negative $\delta^{13} \mathrm{C}$ excursion has been reported only for the Dan-C2 event.

This study is focused on the Danian-Selandian transition in the Eastern Desert of Egypt. This area is part of the southern Tethyan margin and represents an important area for studying processes on the Palaeocene continental margin, as it provides numerous well-exposed sections with well-preserved microfossils from a variety of palaeoenvironmental settings (e.g. Speijer \& Schmitz 1998; Guasti et al. 2006). In particular, Palaeocene sequences in the Nile Basin, Egypt, provide excellent opportunities to identify the signature of global events on biotic and environmental evolution in the subtropical-tropical neritic realm of the southern Tethys (e.g. Speijer \& Schmitz 1998; Speijer 2003). Based on the many micropalaeontological and lithological similarities between the D-S transition and the PETM in Nile Basin sequences (Speijer 2003), and through comparison with preliminary benthic foraminiferal data from the Ocean Drilling Program (ODP; Thomas \& Zachos 2000), it has been suggested that the D-S transition may record one of the earliest Cenozoic hyperthermals (Speijer 2003). 
In addition, the Spanish Zumaia section, which hosts the Global Stratotype and Stratigraphic Point (GSSP) for the Selandian (Schmitz et al. 2008), displays two negative $\delta^{13} \mathrm{C}$ excursions: the first, smaller one with an amplitude of $c .0 .5 \%$ in the lowermost part of magnetochron C26r, and a second one with an amplitude of c. $1 \%$ o just above the lowest occurrence (LO) of Fasciculithus tympaniformis; that is, the base of the calcareous nannofossil biozone NP5 (Arenillas et al. 2008). However, $\delta^{13} \mathrm{C}$ records for the D-S transition are based either on low-resolution records (Egypt and Israel: Charisi \& Schmitz 1998; Wombat Plateau: Quillévéré et al. 2002; Quillévéré \& Norris, 2003) or on bulk-rock analyses (Zumaia section: Schmitz et al. 1997, 1998; Arenillas et al. 2008). Here, the first $\delta^{13} \mathrm{C}$ records are presented from the D-S transition based on benthic foraminifers (Pyramidulina) from four sections in eastern Egypt (Fig. 1).

\section{Biostratigraphy and lithology}

The studied interval covers the planktonic foraminiferal biozones P2-P4 following Berggren \& Pearson (2005), and the calcareous nannofossil zones NP4 and NP5 and NTp6-NTp9 after Martini (1971) and Varol (1989), respectively. A detailed discussion of the biostratigraphy has been given by Steurbaut \& Sztraikos (2008) and Sprong et al. (2009). The Danian and Selandian stages are represented by the upper part of the Dakhla Formation, which is made up of monotonous brownish to grey marls and shales deposited on the generally NW-deepening shelf (Said 1990; Speijer 2003). A prominent centimetre- to decimetre-thick event deposit is intercalated within the marly Dakhla Formation close to the $\mathrm{P} 3 \mathrm{a}-\mathrm{P} 3 \mathrm{~b}$ planktonic foraminiferal subzonal boundary (Sprong et al. 2009). The lower contact of the event deposit with the enclosing Dakhla beds is sharp and possibly unconformable (Speijer 2003; Sprong et al. 2009).

Two sections have been studied at Gebel Qreiya, named Qreiya 1 and Qreiya 3. Qreiya 1 is located on the western rim of Gebel Qreiya $\left(26^{\circ} 30.188^{\prime} \mathrm{N}, 32^{\circ} 52.305^{\prime} \mathrm{E}\right)$, and Qreiya 3 is located near the southern tip of Gebel Qreiya $\left(26^{\circ} 27.702^{\prime} \mathrm{N}\right.$, $\left.33^{\circ} 1.905^{\prime} \mathrm{E}\right)$. At both sections lower Danian to Ypresian sediments attain a thickness of $c .100 \mathrm{~m}$ (Said 1990). The palaeobathymetry has been estimated at 150-250 m (Speijer 2003; Sprong et al. 2009). The upper Danian event deposits consist of two distinct beds (beds I and II). At Qreiya 1, laminated dark brown-pinkish marl beds interrupt the sediments of the Dakhla Formation from 4.10 to $4.22 \mathrm{~m}$. The lowermost $2 \mathrm{~cm}$ are rich in coprolites and planktonic foraminifers (= upper part bed I), followed up-section by a dark greyish shale of $6 \mathrm{~cm}$ thickness. The uppermost $4 \mathrm{~cm}$ are again laminated brown marls with clay pebbles, fish remains and abundant planktonic foraminifers. Two metres higher up-section $(6.6 \mathrm{~m})$ a channel bed of $5 \mathrm{~cm}$ thickness occurs, and from $10.2 \mathrm{~m}$ upwards the carbonate content of the marls increases gradually. At Qreiya 3 the base of the upper Danian event beds is positioned at $8.20 \mathrm{~m}$, measured from the base of the wadi floor. The uppermost $15 \mathrm{~cm}$ of the grey marl below the event beds are dark grey and bioturbated at the top. Bed I (8.2-8.3 m) consists of a dark pinkish brown, organic-rich laminated marl (up to $3.5 \mathrm{wt} \%$ total organic carbon (TOC), L. Schwark, pers. comm.) containing fish remains, coprolites and planktonic foraminifers. The upper $7 \mathrm{~cm}$ of bed I are again made of the pinkish brown laminated marls. Parallel to the lamination dark grey clay lenses are present, which represent downward bioturbation from bed II $(8.3-8.5 \mathrm{~m})$, which is a grey marly shale and contains hematitic or limonitic bivalve and gastropod moulds.

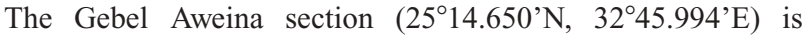
located east of the Nile Valley, about $50 \mathrm{~km}$ south of Luxor. The palaeobathymetry of this section has been estimated at 150$250 \mathrm{~m}$ (Speijer \& Schmitz 1998; Speijer 2003; Sprong et al. 2009), probably slightly shallower than the Qreiya sections. The lower Palaeogene succession is more than $150 \mathrm{~m}$ thick. The upper Danian event beds are situated c. $25 \mathrm{~m}$ above the Cretaceous-Palaeogene (K-P) boundary (Speijer \& Schmitz 1998) within the marls of the Dakhla Formation and attain a thickness of only $5 \mathrm{~cm}$. The lowermost $3 \mathrm{~cm}$ consist of laminated dark brown-pinkish marls filled with coprolites and high numbers of planktonic foraminifers (upper part bed I), whereas the remaining $2 \mathrm{~cm}$ consist of a dark grey shale (bed II) with remains of bivalves and gastropods.

The Gebel Duwi section ( $\left.26^{\circ} 06.093^{\prime} \mathrm{N}, 34^{\circ} 06.707^{\prime} \mathrm{E}\right)$ is located about $15 \mathrm{~km}$ inland from the Red Sea coast, west of Quseir, and represents the shallowest section studied $(70-150 \mathrm{~m}$; Speijer 2003). The studied part spans $12 \mathrm{~m}$ of the Dakhla Formation and starts $32 \mathrm{~m}$ above the K-P boundary. At $37.6 \mathrm{~m}$ the grey marls are interrupted by the event deposit, which is represented by a single light grey sandy marl bed of $10 \mathrm{~cm}$ thickness that shows

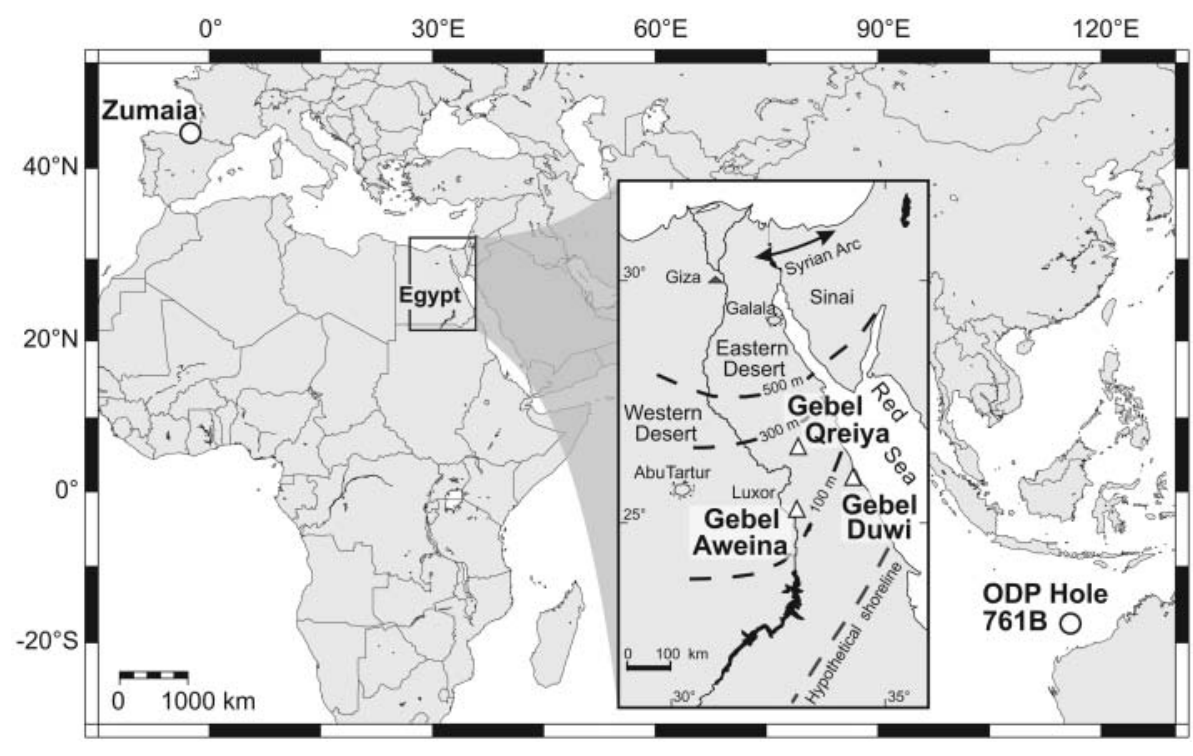

Fig. 1. Map showing the locations of the sections studied and others mentioned in the text. Egypt inset displays the detailed location of the studied sections, which are located along a palaeobathymetric gradient; projected palaeoisobaths are indicated. 
no particular enrichment in organic matter, but fines upwards, with bioturbation and lamination in the lowermost $5 \mathrm{~cm}$. In addition, it also contains fish remains and coprolites.

\section{Methods}

Samples were dried for at least $24 \mathrm{~h}$ at $60{ }^{\circ} \mathrm{C}$ and then soaked in a $50 \mathrm{~g}^{-1} \mathrm{Na}_{2} \mathrm{CO}_{3}$ solution for $24 \mathrm{~h} . \delta^{13} \mathrm{C}$ analyses were performed on well-preserved specimens of the nodosariid benthic foraminifers Pyramidulina latejugata and P. macneili. The specimens were picked from the $>250 \mu \mathrm{m}$ fraction, the shells were cracked between two glass slides and the resulting fragments were separated manually from the infilling. Shell material was cleaned with a picking needle and distilled water. The shell carbonate was reacted with $100 \%$ phosphoric acid at $75^{\circ} \mathrm{C}$ using a Kiel III online carbonate preparation line connected to a ThermoFinnigan 252 mass spectrometer. Reproducibility was checked by replicate analysis of laboratory standards and was better than $\pm 0.05 \%$ and $0.06 \%$ o $(1 \sigma)$ for $\delta^{13} \mathrm{C}$ and $\delta^{18} \mathrm{O}$, respectively. All values are reported in per mil relative to VPDB by assigning a $\delta^{13} \mathrm{C}$ value of $+1.95 \%$ and a $\delta^{18} \mathrm{O}$ value of $-2.20 \%$ to NBS19. Results are shown in Table 1.

\section{Results and discussion}

\section{Preservation and life habitat}

Preservation of the shell material was evaluated using scanning electron microscopy (Fig. 2). Secondary cements attached to the shells have not been observed, and the ultrastructure shows original shell structure and pore canals (Fig. 2); however, minor signs of incipient recrystallization have been recognized on some specimens. Therefore, the focus will be mainly on the carbon isotope record, as oxygen isotope values are more prone to diagenetic alteration during burial than carbon isotope values (Marshall 1992).

Pyramidulina species have successfully been used for stable isotope studies of Palaeogene (Charisi \& Schmitz 1998) and Cretaceous sediments (Almogi-Labin et al. 1993; Fassell \& Bralower 1999). Stable isotope data (Shackleton et al. 1984; Fassell \& Bralower 1999) and morphological studies (Koutsoukos \& Hart 1990) have suggested that Pyramidulina had either an epifaunal (Shackleton et al. 1984; Koutsoukos \& Hart 1990) or a shallow infaunal lifestyle (Koutsoukos \& Hart 1990; Fassell \& Bralower 1999). Data of Fassell \& Bralower (1999) showed a fairly good agreement between $\delta^{13} \mathrm{C}$ trends in epifaunal gavelinellids and Pyramidulina, indicating that this group could be well suited to trace relative changes in bottom water $\delta^{13} \mathrm{C}$.

\section{Late Danian $\delta^{13} \mathrm{C}$ and environmental changes}

All four sections studied show a negative shift of at least $1 \%$ in $\delta^{13} \mathrm{C}$ (Fig. 3), with the most negative values within or above the upper Danian event beds, slightly above the P3a-P3b subzonal boundary as delineated by the LO of Igorina albeari (Sprong et al. 2009). Calcareous nannofossil studies (Gebel Qreiya and Gebel Aweina) correlate this to a level within zones NP4 and lowermost NTp7B (Sprong et al. 2009). At Gebel Duwi, the shallowest section, the excursion seems to be expanded and shows a gradual $2 \%$ shift, suggesting that the magnitude of this excursion might have been greater than $1 \%$. At Gebel Duwi the values start to decline about $1 \mathrm{~m}$ below the event beds, and the most negative values occur slightly above these beds. In both Qreiya sections a second negative excursion of c. $1.3 \%$ was

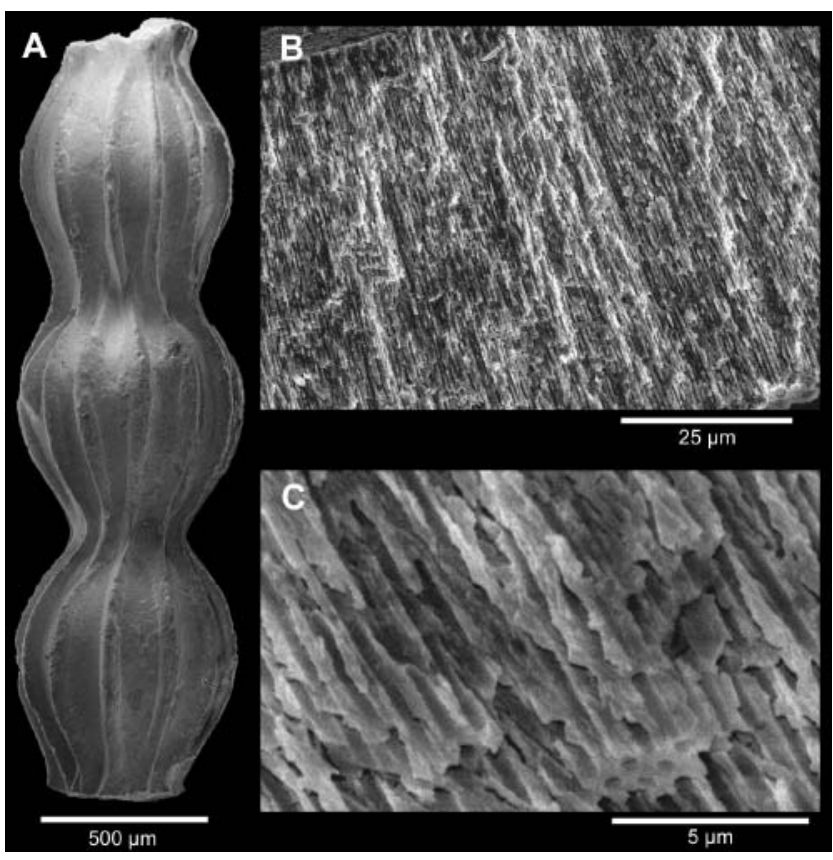

Fig. 2. Scanning electron micrographs of a specimen of the benthic foraminifer Pyramidulina: (a) whole test view; (b, c) detail showing wellpreserved original shell ultrastructure with vertical pore canals.

found close to an unconformity (Fig. 3) at the top of subzone $\mathrm{P} 3 \mathrm{~b}$ and slightly below the NP4-NP5 calcareous nannofossil boundary.

There are two feasible scenarios to explain the prominent negative shift in $\delta^{13} \mathrm{C}$ above the $\mathrm{P} 3 \mathrm{a}-\mathrm{P} 3 \mathrm{~b}$ subzonal boundary. One explanation on a local scale would be that isotopically light $\mathrm{CO}_{2}$, which may be released during degradation of organic matter in the event deposit, has become incorporated into shells of benthic foraminifers, causing a trend in $\delta^{13} \mathrm{C}$ towards negative values. However, this explanation is discarded for three reasons: (1) the $\delta^{13} \mathrm{C}$ excursion is not related to the organic matter rich event deposit in all sections (e.g. at Gebel Duwi; Fig. 3); (2) at Gebel Duwi the $\delta^{13} \mathrm{C}$ values show a decrease below the event bed and minimum values occur above it, and are therefore not caused by the degradation of organic matter; (3) there is ample stratigraphical evidence (Steurbaut \& Sztrákos 2008; Sprong et al. 2009) that this excursion has a supra-regional nature, as it is also known from northern Spain (Zumaia, 900-1100 m water depth, North Atlantic Ocean; Arenillas et al. 2008; Fig. 3).

The second explanation is similar to that suggested for the PETM (e.g. Dickens et al. 1997): huge amounts of isotopically light carbon may have been added to the ocean-atmosphere system, possibly as a result of the release and subsequent dissociation of methane, or alternatively through oxidation of terrestrial or marine organic carbon, or enhanced volcanic outgassing (e.g. Pagani et al. 2006b). In this case the latest Danian $\delta^{13} \mathrm{C}$ excursion should also occur in other oceanic basins.

In Egypt several palaeoenvironmental characteristics of this Latest Danian Event (LDE) are similar to those of the PETM (Speijer 2003; see Table 2 for a summary). The most prominent similarities are: (1) low levels of bottom-water oxygenation have caused enhanced preservation of organic matter during both events; (2) both event deposits show a very high planktonic/ benthic foraminiferal ratio, and the benthic foraminiferal assemblage is dominated by opportunistic taxa indicating shallow water (Neoeponides duwi in the latest Danian, and Anomalinoides 
Table 1. Comparison of sedimentary and biotic characteristics between the Latest Danian Event, the PETM and the background sedimentation (modified from Speijer 2003)

\begin{tabular}{|c|c|c|c|}
\hline Section & Depth (m) & $\delta^{13} \mathrm{C}(\%$ PDB $)$ & $\delta^{18} \mathrm{O}(\%$ PDB $)$ \\
\hline Gebel Qreiya 1 & 1.00 & -0.39 & -2.35 \\
\hline Gebel Qreiya 1 & 1.50 & -0.46 & -2.06 \\
\hline Gebel Qreiya 1 & 3.50 & -0.32 & -2.03 \\
\hline Gebel Qreiya 1 & 3.70 & -0.70 & -2.01 \\
\hline Gebel Qreiya 1 & 3.95 & -0.61 & -2.42 \\
\hline Gebel Qreiya 1 & 4.10 & -0.98 & -2.84 \\
\hline Gebel Qreiya 1 & 4.12 & -1.22 & -2.88 \\
\hline Gebel Qreiya 1 & 4.17 & -0.95 & -2.45 \\
\hline Gebel Qreiya 1 & 4.18 & -0.45 & -2.48 \\
\hline Gebel Qreiya 1 & 4.19 & -0.97 & -2.46 \\
\hline Gebel Qreiya 1 & 4.22 & -0.72 & -2.46 \\
\hline Gebel Qreiya 1 & 4.60 & 0.00 & -2.08 \\
\hline Gebel Qreiya 1 & 4.90 & -0.28 & -3.55 \\
\hline Gebel Qreiya 1 & 5.50 & -0.12 & -1.90 \\
\hline Gebel Qreiya 1 & 5.50 & -0.26 & -2.95 \\
\hline Gebel Qreiya 1 & 6.00 & -1.40 & -1.93 \\
\hline Gebel Qreiya 1 & 6.70 & -0.82 & -3.63 \\
\hline Gebel Qreiya 1 & 8.20 & -0.14 & -2.03 \\
\hline Gebel Qreiya 1 & 8.70 & -0.59 & -2.74 \\
\hline Gebel Qreiya 1 & 9.20 & -0.34 & -2.71 \\
\hline Gebel Qreiya 1 & 9.70 & -0.21 & -2.16 \\
\hline Gebel Qreiya 3 & 0.00 & -0.18 & -1.72 \\
\hline Gebel Qreiya 3 & 0.00 & -0.36 & -1.81 \\
\hline Gebel Qreiya 3 & 0.24 & -0.14 & -2.47 \\
\hline Gebel Qreiya 3 & 0.72 & -0.18 & -1.99 \\
\hline Gebel Qreiya 3 & 0.97 & -0.22 & -1.51 \\
\hline Gebel Qreiya 3 & 1.45 & -0.28 & -1.55 \\
\hline Gebel Qreiya 3 & 1.69 & -0.26 & -1.89 \\
\hline Gebel Qreiya 3 & 2.17 & -0.17 & -1.43 \\
\hline Gebel Qreiya 3 & 2.41 & 0.44 & -1.45 \\
\hline Gebel Qreiya 3 & 4.34 & -0.11 & -2.38 \\
\hline Gebel Qreiya 3 & 4.34 & -0.16 & -2.32 \\
\hline Gebel Qreiya 3 & 4.34 & -0.48 & -2.28 \\
\hline Gebel Qreiya 3 & 5.31 & -0.29 & -2.09 \\
\hline Gebel Qreiya 3 & 5.55 & -0.29 & -1.94 \\
\hline Gebel Qreiya 3 & 6.28 & -0.65 & -1.37 \\
\hline Gebel Qreiya 3 & 7.00 & -0.01 & -1.47 \\
\hline Gebel Qreiya 3 & 7.50 & 0.00 & -1.56 \\
\hline Gebel Qreiya 3 & 8.00 & -0.94 & -2.24 \\
\hline Gebel Qreiya 3 & 8.32 & -0.97 & -1.90 \\
\hline Gebel Qreiya 3 & 8.35 & -1.28 & -1.74 \\
\hline Gebel Qreiya 3 & 8.42 & -0.43 & -1.59 \\
\hline Gebel Qreiya 3 & 8.50 & -0.90 & -2.24 \\
\hline Gebel Qreiya 3 & 9.21 & -1.06 & -1.54 \\
\hline Gebel Qreiya 3 & 9.45 & -0.48 & -1.56 \\
\hline Gebel Qreiya 3 & 9.92 & -0.91 & -1.38 \\
\hline Gebel Qreiya 3 & 9.92 & -0.77 & -1.54 \\
\hline Gebel Qreiya 3 & 11.10 & 0.05 & -1.07 \\
\hline Gebel Qreiya 3 & 11.34 & -0.44 & -2.05 \\
\hline Gebel Qreiya 3 & 11.57 & -0.36 & -2.04 \\
\hline Gebel Qreiya 3 & 11.81 & -0.05 & -1.74 \\
\hline Gebel Qreiya 3 & 12.05 & -0.57 & -2.09 \\
\hline Gebel Qreiya 3 & 12.28 & -0.54 & -1.95 \\
\hline Gebel Qreiya 3 & 12.75 & -0.46 & -2.21 \\
\hline Gebel Qreiya 3 & 13.23 & -0.72 & -1.84 \\
\hline Gebel Qreiya 3 & 13.70 & -0.85 & -2.33 \\
\hline Gebel Qreiya 3 & 13.94 & 0.27 & -2.11 \\
\hline Gebel Qreiya 3 & 15.44 & 0.19 & -1.79 \\
\hline Gebel Aweina 95 & 19.00 & -0.46 & -2.33 \\
\hline Gebel Aweina 95 & 22.00 & -0.06 & -2.08 \\
\hline Gebel Aweina 95 & 23.00 & 0.05 & -1.93 \\
\hline Gebel Aweina 95 & 25.45 & -0.56 & -2.33 \\
\hline Gebel Aweina 95 & 25.68 & -1.18 & -2.09 \\
\hline Gebel Aweina 95 & 25.79 & -1.03 & -2.17 \\
\hline Gebel Aweina 95 & 25.88 & -1.76 & -2.44 \\
\hline Gebel Aweina 95 & 25.94 & -1.47 & -2.19 \\
\hline Gebel Aweina 95 & 25.98 & -1.87 & -2.51 \\
\hline Gebel Aweina 95 & 26.00 & -0.62 & $\begin{array}{c}-2.45 \\
\quad \text { contin }\end{array}$ \\
\hline
\end{tabular}

Table 1. (continued)

\begin{tabular}{|c|c|c|c|}
\hline Section & Depth (m) & $\delta^{13} \mathrm{C}$ (\%о PDB) & $\delta^{18} \mathrm{O}(\%$ PDB $)$ \\
\hline Gebel Aweina 95 & 26.03 & -1.05 & -2.86 \\
\hline Gebel Aweina 95 & 26.07 & -1.15 & -2.45 \\
\hline Gebel Aweina 95 & 26.11 & -1.59 & -2.50 \\
\hline Gebel Aweina 95 & 26.22 & -1.34 & -2.53 \\
\hline Gebel Aweina 95 & 26.38 & -1.03 & -2.11 \\
\hline Gebel Aweina 95 & 26.48 & -0.63 & -2.28 \\
\hline Gebel Aweina 95 & 26.58 & -0.71 & -1.95 \\
\hline Gebel Aweina 95 & 26.68 & -0.93 & -2.02 \\
\hline Gebel Aweina 95 & 26.95 & -0.82 & -2.55 \\
\hline Gebel Aweina 95 & 27.25 & -0.54 & -2.24 \\
\hline Gebel Aweina 95 & 27.75 & -0.95 & -2.59 \\
\hline Gebel Aweina 95 & 28.25 & -0.85 & -2.56 \\
\hline Gebel Aweina 95 & 28.50 & -0.33 & -2.37 \\
\hline Gebel Aweina 95 & 28.75 & -0.35 & -1.91 \\
\hline Gebel Aweina 95 & 29.00 & 0.12 & -2.06 \\
\hline Gebel Aweina 95 & 31.00 & -0.61 & -2.31 \\
\hline Gebel Aweina 95 & 34.00 & 0.04 & -1.96 \\
\hline Gebel Aweina 95 & 35.00 & -0.37 & -2.52 \\
\hline Gebel Aweina 06 & 25.75 & -1.16 & -2.55 \\
\hline Gebel Aweina 06 & 25.85 & -0.87 & -2.57 \\
\hline Gebel Aweina 06 & 25.90 & -1.21 & -2.66 \\
\hline Gebel Aweina 06 & 25.95 & -1.28 & -2.80 \\
\hline Gebel Aweina 06 & 25.99 & -0.54 & -2.64 \\
\hline Gebel Aweina 06 & 26.01 & -0.61 & -2.06 \\
\hline Gebel Aweina 06 & 26.02 & -0.93 & -2.52 \\
\hline Gebel Aweina 06 & 26.05 & -0.56 & -2.23 \\
\hline Gebel Aweina 06 & 26.10 & -0.84 & -2.23 \\
\hline Gebel Aweina 06 & 26.15 & -0.78 & -2.64 \\
\hline Gebel Aweina 06 & 26.25 & -0.50 & -2.48 \\
\hline Gebel Duwi 95 & 30.07 & -0.08 & -1.68 \\
\hline Gebel Duwi 95 & 31.01 & -0.34 & -1.49 \\
\hline Gebel Duwi 95 & 31.78 & -0.22 & -1.94 \\
\hline Gebel Duwi 95 & 32.57 & 0.00 & -1.61 \\
\hline Gebel Duwi 95 & 33.34 & 0.16 & -1.75 \\
\hline Gebel Duwi 95 & 34.12 & -0.28 & -1.77 \\
\hline Gebel Duwi 95 & 34.91 & -0.15 & -1.58 \\
\hline Gebel Duwi 95 & 35.70 & -0.02 & -1.41 \\
\hline Gebel Duwi 95 & 36.64 & -0.14 & -1.62 \\
\hline Gebel Duwi 95 & 37.58 & -1.32 & -2.46 \\
\hline Gebel Duwi 95 & 38.05 & -0.52 & -1.59 \\
\hline Gebel Duwi 95 & 38.05 & -0.47 & -1.41 \\
\hline Gebel Duwi 95 & 38.52 & -0.67 & -1.61 \\
\hline Gebel Duwi 95 & 40.40 & -0.09 & -2.39 \\
\hline Gebel Duwi 95 & 41.34 & -0.99 & -1.27 \\
\hline Gebel Duwi 95 & 42.28 & -0.08 & -1.47 \\
\hline Gebel Duwi 95 & 43.22 & 0.06 & -1.61 \\
\hline Gebel Duwi 06 & 34.11 & 0.15 & -1.73 \\
\hline Gebel Duwi 06 & 34.51 & 0.11 & -1.49 \\
\hline Gebel Duwi 06 & 34.98 & -0.44 & -2.20 \\
\hline Gebel Duwi 06 & 35.38 & -0.59 & -2.10 \\
\hline Gebel Duwi 06 & 35.78 & -0.35 & -1.78 \\
\hline Gebel Duwi 06 & 36.18 & -0.19 & -1.69 \\
\hline Gebel Duwi 06 & 36.58 & -0.32 & -2.18 \\
\hline Gebel Duwi 06 & 36.98 & -0.33 & -2.28 \\
\hline Gebel Duwi 06 & 37.18 & 0.15 & -1.98 \\
\hline Gebel Duwi 06 & 37.38 & -0.49 & -1.79 \\
\hline Gebel Duwi 06 & 37.43 & -0.23 & -2.07 \\
\hline Gebel Duwi 06 & 37.48 & -0.32 & -1.87 \\
\hline Gebel Duwi 06 & 37.57 & -0.76 & -1.73 \\
\hline Gebel Duwi 06 & 37.58 & -0.83 & -2.14 \\
\hline Gebel Duwi 06 & 37.66 & 0.07 & -1.70 \\
\hline Gebel Duwi 06 & 37.71 & -0.98 & -1.90 \\
\hline Gebel Duwi 06 & 37.76 & -0.77 & -1.73 \\
\hline Gebel Duwi 06 & 37.81 & -0.49 & -1.40 \\
\hline Gebel Duwi 06 & 37.83 & -1.46 & -1.93 \\
\hline Gebel Duwi 06 & 37.98 & -0.51 & -1.50 \\
\hline Gebel Duwi 06 & 38.18 & -2.05 & -1.95 \\
\hline Gebel Duwi 06 & 38.38 & -1.50 & -2.14 \\
\hline Gebel Duwi 06 & 38.78 & -0.84 & -2.03 \\
\hline Gebel Duwi 06 & 39.18 & -1.56 & -2.52 \\
\hline
\end{tabular}



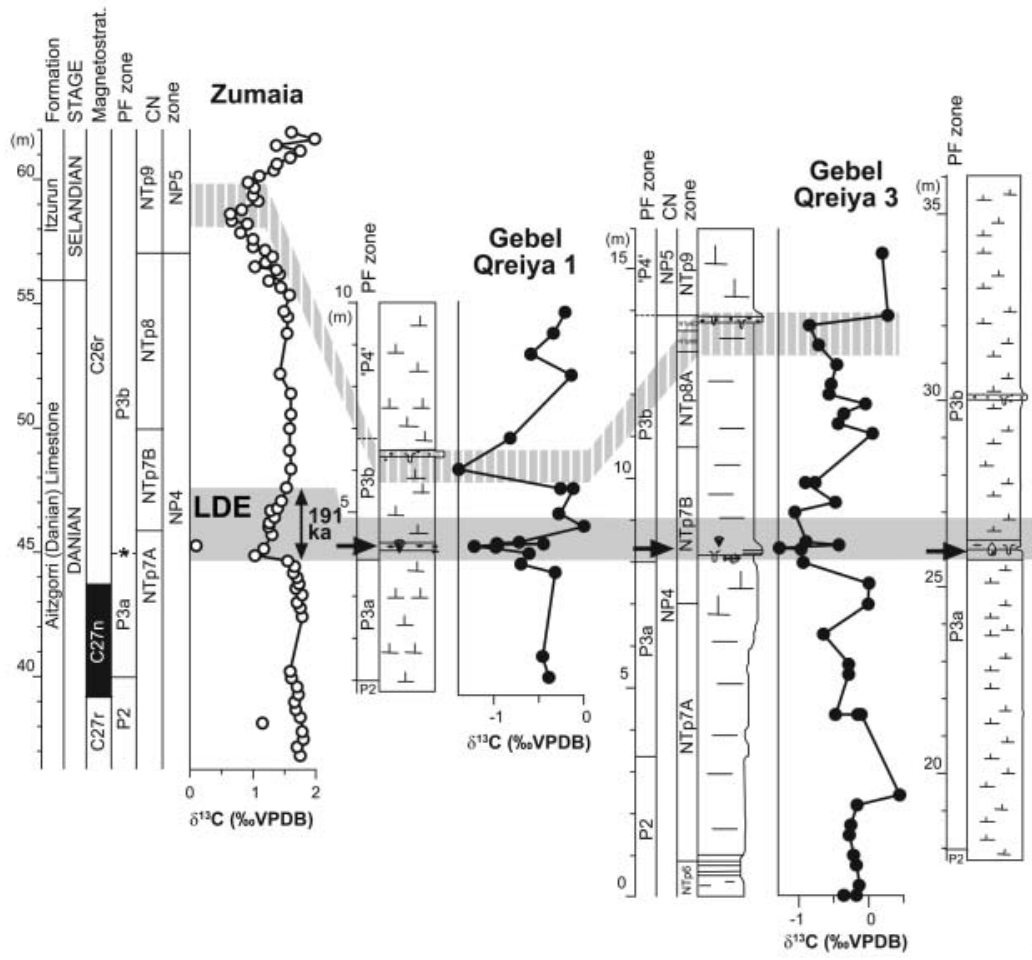

Gebe

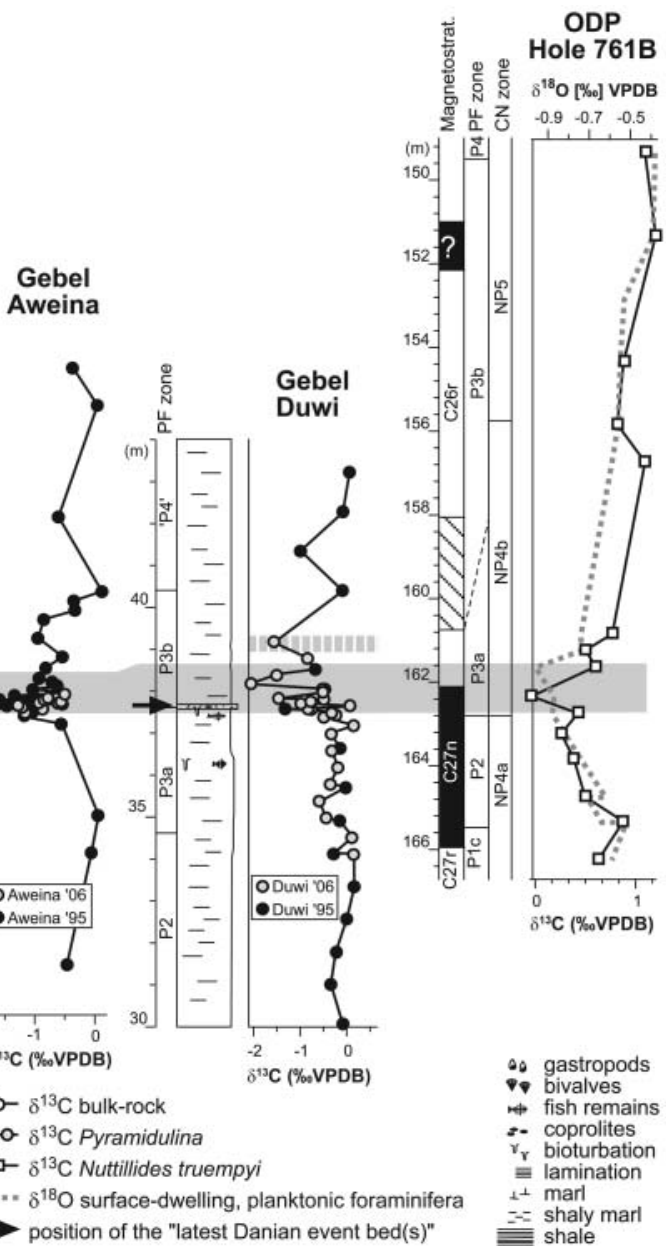

Fig. 3. Lithology, stratigraphy and benthic foraminiferal $\delta^{13} \mathrm{C}$ records from four sections (Gebel Qreiya 1, Gebel Qreiya 3, Gebel Aweina, Gebel Duwi) in the Nile Basin (Egypt), and their correlation with the Selandian GSSP succession at Zumaia (Spain, Arenillas et al. 2008) and ODP Hole 761B (offshore NW Australia, Quillévéré et al. 2002; Quillévéré \& Norris 2003). The P3a-P3b planktonic foraminiferal subzonal boundary (*) at Zumaia has been changed with respect to Arenillas et al. (2008). Taxonomic comparisons reveal that Igorina cf. albeari (also named Morozovella crosswicksensis) of Arenillas et al. (2008) is identical to our concept of I. albeari and the P3a-b subzonal boundary has consequently been moved downwards (see also discussion by Sprong et al. 2009). Grey shaded area represents the correlation between Zumaia and the Egyptian section for the Latest Danian Event; the dashed grey band shows a tentative correlation for the upper $\delta^{13} \mathrm{C}$ excursion at Zumaia.

Table 2. Comparison of sedimentary and biotic characteristics between the Late Danian Event, the PETM and the background sedimentation (modified from Speijer 2003)

\begin{tabular}{llll}
\hline Parameter & Late Danian Event & PETM & Palaeocene background \\
\hline Lithology/geochemistry & Dark brown marl & Dark brown marl & Grey to pale brown marl \\
Predominant lithology & Unconformity & Some distinct & Some paraconformities \\
Discontinuities & Transgressive & Transgressive & Various \\
Systems tract & Abundant & Abundant & Rare \\
Fish remains & $0.8-3.5$ & $1.5-2.7$ & $<0.3$ \\
TOC $(\%)$ & Negative excursion $\leqslant 2 \%$ & Negative excursion $\leqslant 3 \% 0$ & Long-term variation \\
$\delta^{13} \mathrm{C}$ trends & & & $70-95$ \\
Biotalforaminifers & $2-99.8$ & c. 99 & Common to abundant \\
Planktonic foraminifers $>125 \mu \mathrm{m}(\%)$ & Rare & Rare & Common to abundant \\
Morozovella & Dominant & Dominant & Diverse \\
Praemurica and Acarinina & Oligotaxic & Oligotaxic & Depth dependent \\
Benthic assemblage & Neoeponides duwi & Anomalinoides aegyptiacus & Good to moderate \\
Dominant benthic taxon & Poor & Poor (variable?) & \\
Oxygenation at sea floor & &
\end{tabular}


aegyptiacus during the PETM); (3) the upper Danian event beds represent an unconformity (probably Sel-1 after Hardenbol et al. 1998) followed by a sea-level rise, which is similar to the sealevel scenario suggested for the PETM deposits in Egypt (Speijer \& Wagner 2002).

The $\delta^{18} \mathrm{O}$ data, which are reported in Table 1 , show no unequivocal shift that supports bottom-water warming during the LDE that would make a strong case for a hyperthermal event. In general, the data are very noisy with no distinct pattern. This is not unique for studies on the southern Tethyan margin. Even for the well-known PETM, no $\delta^{18} \mathrm{O}$ record exists from this area that shows a distinctive change towards lighter $\delta^{18} \mathrm{O}$ values of foraminiferal calcite. The absence of such an isotope shift may result from various factors: in contrast to the deep sea, where bottom-water temperatures and continental ice volume are the main driving factors, shelf sediments are also influenced by evaporation-precipitation changes as well as by river discharge, which both may bias the $\delta^{18} \mathrm{O}$ values. In addition, a diagenetic influence can never be ruled out if sediments crop out on the Earth's surface, and as pointed out above, some shells show signs of incipient diagenesis. Nevertheless, the similarities between the PETM and the LDE with respect to their palaeoenvironmental consequences (Table 2) suggest that the mechanisms that caused the two events were very similar or even identical. This conclusion leads to the hypothesis that the LDE represents another Cenozoic hyperthermal event, which is supported by the supraregional occurrence of the event.

\section{Supra-regional significance of the latest Danian negative $\delta^{13} C$ excursion}

Whole-rock $\delta^{13} \mathrm{C}$ data from Zumaia (Schmitz et al. 1997, 1998; Arenillas et al. 2008) show two negative excursions of up to $1 \%$ at a stratigraphical level that can be confidently correlated with Gebel Qreiya 1 and 3 (Fig. 3). The first excursion is situated in the basal metres of the Itzurun Formation, and the second one is located c. $10 \mathrm{~m}$ lower at the transition from limestone to limestone-marl couplets at the top of the Danian Aitzgorri Limestone Formation. The latter lithological change and carbon isotope excursion correlate biostratigraphically with the upper Danian event beds at the P3a-P3b planktonic foraminiferal boundary, and correspond approximately to the NTp7A-B calcareous nannofossil boundary (Steurbaut \& Sztrákos 2008; Sprong et al. 2009).

Sample resolution from the Egyptian sections is too low to allow the testing of orbital pacing for the latest Danian $\delta^{13} \mathrm{C}$ event, as observed for other younger hyperthermals (e.g. Cramer et al. 2003; Lourens et al. 2005). Furthermore, the existence of an unconformity in at least some of the sections studied hampers an estimation of the timing of this event. Here the calculation of the duration of this $\delta^{13} \mathrm{C}$ event is based on the biostratigraphical correlation between Zumaia and Egypt. At Zumaia average sedimentation rates of $1.33 \mathrm{~cm} \mathrm{ka}^{-1}$ for magnetochrons $\mathrm{C} 27 \mathrm{n}$ $\left(1.36 \mathrm{~cm} \mathrm{ka}^{-1}\right)$ and $\mathrm{C} 26 \mathrm{r}\left(1.29 \mathrm{~cm} \mathrm{ka}^{-1}\right)$ have been calculated by Dinares-Turell et al. (2007), resulting in a total duration of 191 ka for the $\delta^{13} \mathrm{C}$ anomaly (Fig. 3), which is comparable with the duration of the PETM (Röhl et al. 2000, 2007).

Further anomalies at the top of magnetochron C27n and above were identified by Westerhold et al. (2008), who found two prominent peaks in $\mathrm{Fe}$ intensities from X-ray fluorescence scanning and magnetic susceptibility ('Top Chron 27n Event') at various ODP sites on Walvis Ridge, Shatsky Rise and in the Caribbean Sea, which are similar to the PETM interval. These two peaks correspond to the two short eccentricity cycles 38 and 39 according to the astronomical Palaeocene time scale of Westerhold et al. (2008). Only one of these peaks occurs above Top C27n magnetochron as the LDE at Zumaia (Fig. 3). This suggests a duration of $\leqslant 100 \mathrm{ka}$ for the LDE, in contrast to the cyclostratigraphic results from Zumaia. The C27n-C26r transition is further characterized by a significant increase in oceanic spreading rates (Westerhold et al. 2008) and enhanced volcanic activity at the SE Greenland margin (Sinton \& Duncan 1998), which might be related to the palaeoenvironmental changes reported for the latest Danian by Speijer (2003) and herein.

Whereas the first negative $\delta^{13} \mathrm{C}$ excursion is well constrained, the second one is represented by only a few spot measurements. Therefore it is hard to make a case for a global $\delta^{13} \mathrm{C}$ excursion, although a second negative $\delta^{13} \mathrm{C}$ excursion is documented at Zumaia. According to Westerhold et al. (2008), this anomaly should correspond to the short eccentricity cycles 48 and/or 49 , which show no distinctive change in the Fe intensities.

A negative $\delta^{13} \mathrm{C}$ shift of c. $0.6 \%$ in benthic and deep-dwelling planktonic foraminifers has also been reported by Quillévéré et al. (2002) and Quillévéré \& Norris (2003) from the Wombat Plateau (Indian Ocean, ODP Hole 761B), which was followed by a slight $\left(2-3^{\circ} \mathrm{C}\right)$ surface-water warming (Fig. 3). The late Danian $\delta^{13} \mathrm{C}$ excursion at the Wombat Plateau comprises the upper part of magnetochron $\mathrm{C} 27 \mathrm{n}$ and the lowermost part of magnetochron 26r; however, benthic foraminifers display the most negative numbers after a $c .0 .5 \mathrm{Ma}$ hiatus (P3a, NP4a) above magnetochron $\mathrm{C} 27 \mathrm{n}$. It is reasonable to consider that this excursion might represent the same event as in the Egyptian sections and the lower one at Zumaia, which is situated a short distance above the C27n-C26r boundary (Arenillas et al. 2008). Although Quillévéré \& Norris (2003) followed the same taxonomic criteria for $I$. albeari as employed here (F. Quillévéré, pers. comm.), they assigned the $\delta^{13} \mathrm{C}$ shift to biozone P3a. It is proposed that the large distance between the present sections and the Wombat Plateau, and their different environmental settings, make a slight diachrony in the first appearance of I. albeari likely, so the magnetostratigraphic age assignment is preferred to biostratigraphy for long-distance correlation purposes.

In conclusion, because of the supra-regional nature and the associated palaeoenvironmental changes that are similar to those for the PETM in Egypt (Speijer 2003; Westerhold et al. 2008), it is hypothesized that the negative $\delta^{13} \mathrm{C}$ excursion at the $\mathrm{P} 3 \mathrm{a}-\mathrm{P} 3 \mathrm{~b}$ boundary may represent an additional Palaeocene hyperthermal, although reliable temperature data remain lacking for this interval. Various approaches to estimate the duration of the Latest Danian Event suggest that the carbon isotope anomaly lasted between 100 and $191 \mathrm{ka}$. Until now, age-equivalent deepsea sections have been sparsely studied and await further investigation to explore the potential global nature of the event.

We thank T. Westerhold (University of Bremen) for discussions, and M. Joachimski (University of Erlangen) for comments on an earlier version of the manuscript and stable isotope analyses. We further acknowledge J. Lenzner (University of Leipzig) for his help with the SEM, and L. Schwark (University of Kiel) for TOC data. Thoughtful reviews by T. Bralower, R. Norris and I. Jarvis helped to improve the quality of the manuscript. Financial support for this project was provided by FWO and K.U.Leuven Research Fund to R.P.S. and E.S.

\section{References}

Almogi-Labin, A., Bein, A. \& Sass, E. 1993. Late Cretaceous upwelling system along the Southern Tethys Margin (Israel) - Interrelationship between productivity, bottom water environments, and organic-matter preservation. Paleocea- 
nography, 8, 671-690.

Arenillas, I., Molina, E., Ortiz, S. \& Schmitz, B. 2008. Foraminiferal and $\delta^{13} \mathrm{C}$ isotopic event-stratigraphy across the Danian-Selandian transition at Zumaya (northern Spain): chronostratigraphic implications. Terra Nova, 20, $38-44$.

Berggren, W.A. \& Pearson, P.N. 2005. A revised tropical to subtropical Paleogene planktonic foraminiferal zonation. Journal of Foraminiferal Research, 35, 279-298.

Bernaola, G., Baceta, J.I., Orue-Etxebarria, X., Alegret, L., Martin-Rubio, M., Arostegui, J. \& Dinares-Turell, J. 2007. Evidence of an abrupt environmental disruption during the mid-Paleocene biotic event (Zumaia section, western Pyrenees). Geological Society of America Bulletin, 119, $785-795$.

Bowen, G.J., Beerling, D.J., Koch, P.L., Zachos, J.C. \& Quattlebaum, T. 2004. A humid climate state during the Palaeocene/Eocene thermal maximum. Nature, 432, 495-499.

Bralower, T.J., Zachos, J.C., Thomas, E., ET AL. 1995. Late Paleocene to Eocene paleoceanography of the equatorial Pacific Ocean-stable isotopes recorded at Ocean Drilling Program Site 865, Allison Guyot. Paleoceanography, 10, $841-865$.

Bralower, T.J., Premoli Silva, I. \& Malone, M.J. 2002. New evidence for abrupt climate change in the Cretaceous and Paleogene: An Ocean Drilling Program expedition to Shatsky Rise, northwest Pacific. GSA Today, 12, 4-10.

Charisi, S.D. \& Schmitz, B. 1998. Paleocene to early Eocene paleoceanography of the Middle East: The $\delta^{13} \mathrm{C}$ and $\delta^{18} \mathrm{O}$ isotopes from foraminiferal calcite. Paleoceanography, 13, 106-118.

Cramer, B.S., Wright, J.D., Kent, D.V. \& Aubry, M.P. 2003. Orbital climate forcing of $\delta^{13} \mathrm{C}$ excursions in the late Paleocene-early Eocene (chrons C24n-C25n). Paleoceanography, 18, doi:10.1029/2003PA000909.

Dickens, G.R., Castillo, M.M. \& Walker, J.C.G. 1997. A blast of gas in the latest Paleocene: simulating first-order effects of massive dissociation of oceanic methane hydrate. Geology, 25, 259-262.

Dinares-Turell, J., Baceta, J.I., Bernaola, G., Orue-Etxebarria, X. \& Pujalte, V. 2007. Closing the Mid-Palaeocene gap: Toward a complete astronomically tuned Palaeocene Epoch and Selandian and Thanetian GSSPs at Zumaia (Basque Basin, W Pyrenees). Earth and Planetary Science Letters, 262, 450-467.

FAsSell, M.L. \& Bralower, T.J. 1999. Warm, equable mid-Cretaceous: Stable isotope evidence. In: Barrera, E. \& Johnson, C.C. (eds) Evolution of the Cretaceous Ocean-Climate System, Geological Society of America, Special Papers, 332, $121-142$.

Guasti, E., Speijer, R.P., Brinkhuis, H., Smit, J. \& Steurbaut, E. 2006. Paleoenvironmental change at the Danian-Selandian transition in Tunisia: Foraminifera, organic-walled dinoflagellate cyst and calcareous nannofossil records. Marine Micropaleontology, 59, 210-229.

Hardenbol, J., Thierry, J., Farley, M.B., De Graciansky, P.-C. \& Vail, P.R. 1998. Mesozoic and Cenozoic sequence chronostratigraphic framework of European Basins. In: De Graciansky, P.C., Hardenbol, J., Jacquin, T. \& VAIL, P. (eds) Mesozoic and Cenozoic sequence chronostratigraphic framework of European Basins. Society for Sedimentary Geology (SEPM), Special Publications, 60, 3-13

Higgins, J.A. \& Schrag, D.P. 2006. Beyond methane: Towards a theory for the Paleocene-Eocene Thermal Maximum. Earth and Planetary Science Letters, 245, 523-537.

Kennett, J.P. \& Stott, L.D. 1991. Abrupt deep-sea warming: Palaeoceanographic changes and benthic extinctions at the end of the Paleocene. Nature, 353 $225-229$.

Koutsoukos, E.A.M. \& HART, M.B. 1990. Cretaceous foraminiferal morphogroup distribution patterns, paleocommunities and trophic structures - a case-study from the Sergipe Basin, Brazil. Transactions of the Royal Society of Edinburgh: Earth Sciences, 81, 221-246.

Lourens, L.J., SluiJs, A., Kroon, D., ET AL. 2005. Astronomical pacing of late Palaeocene to early Eocene global warming events. Nature, 435, 1083-1087.

Marshall, J.D. 1992. Climatic and oceanographic isotopic signals from the carbonate rock record and their preservation. Geological Magazine, 129, $143-160$.

MARTINI, E. 1971. Standard Tertiary and Quaternary calcareous nannoplankton zonation. In: FARINACCI, A. (ed.) Proceedings of the 2nd Planktonic Conference, Rome, 1970, Vol. 2. Tecnoscienza, Rome, 739-785.

Nicolo, M.J., Dickens, G.R., Hollis, C.J. \& Zachos, J.C. 2007. Multiple early Eocene hyperthermals: Their sedimentary expression on the New Zealand continental margin and in the deep sea. Geology, 35, 699-702.

Pagani, M., Pedentchouk, N., Huber, M., et AL. 2006a. Arctic hydrology during global warming at the Palaeocene/Eocene thermal maximum. Nature, 442, 671-675.

Pagani, M., Caldeira, K., Archer, D. \& Zachos, J.C. 2006b. An ancient carbon mystery. Science, 314, 1556-1557.

Petrizzo, M.R. 2005. An early late Paleocene event on Shatsky Rise, northwest
Pacific Ocean (ODP Leg 198): Evidence from planktonic foraminiferal assemblages. In: Bralower, T.J., Premoli-Silva, I. \& Malone, M.J. (eds) Proceedings of the Ocean Drilling Program, Scientific Results, 198, doi:10.2973/odp.proc.sr.198.102.2005.

QUILlÉVÉRÉ, F. \& NORRIS, R.D. 2003. Ecological development of acarininids (planktonic foraminifera) and hydrographic evolution of Paleocene surface waters. In: Wing, S.L., Gingerich, P.D., Schmitz, B. \& Thomas, E. (eds) Causes and Consequences of globally warm climates in the Early Paleogene. Geological Society of America, Special Papers, 369, 223-238.

Quillévéré, F., Aubry, M.P., Norris, R.D. \& Berggren, W.A. 2002. Paleocene oceanography of the eastern subtropical Indian Ocean-An integrated magnetobiostratigraphic and stable isotope study of ODP Hole 761B (Wombat Plateau). Palaeogeography, Palaeoclimatology, Palaeoecology, 184, $371-405$.

Quillévéré, F., Norris, R.D., Kroon, D. \& Wilson, P.A. 2008. Transient ocean warming and shifts in carbon reservoirs during the early Danian. Earth and Planetary Science Letters, 265, 600-615.

Ravizza, G., Norris, R.D., Blusztajn, J. \& Aubry, M.P. 2001. An osmium isotope excursion associated with the late Paleocene thermal maximum: evidence of intensified chemical weathering. Paleoceanography, 16, 155-163.

RöHl, U., Bralower, T.J., Norris, R.D. \& Wefer, G. 2000. New chronology for the late Paleocene thermal maximum and its environmental implications. Geology, 28, 927-930.

Röhl, U., Westerhold, T., Bralower, T.J. \& Zachos, J.C. 2007. On the duration of the Paleocene-Eocene thermal maximum (PETM). Geochemistry, Geophysics, Geosystems, 8, doi:10.1029/2007GC001784.

SAID, R. 1990. The Geology of Egypt. Balkema, Rotterdam.

Schmitz, B., Asaro, F., Molina, E., Monechi, S., von Salis, K. \& Speijer, R.P. 1997. High-resolution iridium, $\delta^{13} \mathrm{C}, \delta^{18} \mathrm{O}$, foraminifera and nannofossil profiles across the latest Paleocene benthic extinction event at Zumaya, Spain. Palaeogeography, Palaeoclimatology, Palaeoecology, 133, 49-68.

Schmitz, B., Molina, E. \& von Salis, K. 1998. The Zumaya section in Spain: A possible global stratotype section for the Selandian and Thanetian stages. Newsletters on Stratigraphy, 36, 35-42.

Schmitz, B., Pujalte, V. \& Nunez-Betelu, K. 2001. Climate and sea-level perturbations during the initial Eocene thermal maximum: evidence from siliciclastic units in the Basque Basin (Ermua, Zumaia and Trabakua Pass), northern Spain. Palaeogeography, Palaeoclimatology, Palaeoecology, 165, 299-320.

Schmitz, B., Alegret, L., Apellaniz, E., eT AL. 2008. Proposed Global Stratotype Sections and Points for the bases of the Selandian and Thanetian stages (Paleocene Series) by the Paleocene Working Group (unpublished report).

Shackleton, N.J., Hall, M.A. \& Boersma, A. 1984. Oxygen and carbon isotope data from Leg 74 foraminifers. In: Moore, T.C. ET AL. (eds) Initial Reports of the Deep Sea Drilling Project, 74. US Government Printing Office, Washington, DC, 599-612.

Sinton, C.W. \& DunCAN, R.A. 1998. ${ }^{40} \mathrm{Ar}-{ }^{39} \mathrm{Ar}$ ages of lavas from the southeas Greenland Margin, ODP Leg 152 and the Rockall Plateau, DSDP Leg 81. In: Saunders, A.D., Larsen, H.C. \& Wise, S.W., JR (eds) Proceedings of the Ocean Drilling Program, Scientific Results, 152. Ocean Drilling Program, College Station, TX, 387-402.

SpeiJer, R.P. 2003. Danian-Selandian sea-level change and biotic excursion on the southern Tethyan margin (Egypt). In: WING, S.L., Gingerich, P.D., Schmitz, B. \& Thomas, E. (eds) Causes and Consequences of globally warm climates in the Early Paleogene. Geological Society of America, Special Papers, 369, 275-290.

SpeiJer, R.P. \& Schmitz, B. 1998. A benthic foraminiferal record of Paleocene sea level and trophic/redox conditions at Gebel Aweina, Egypt. Palaeogeography, Palaeoclimatology, Palaeoecology, 137, 79-101.

SPEIJER, R.P. \& WAGNER, T. 2002. Sea-level changes and black shales associated with the late Paleocene thermal maximum; organic-geochemical and micropaleontologic evidence from the southern Tethyan margin (EgyptIsrael). In: KoeberL, C. \& MACLeod, K.G. (eds) Catastrophic Events and Mass Extinctions. Geological Society of America, Special Papers, 356, 533 549.

Sprong, J., SpeiJer, R.P. \& Steurbaut, E. 2009. Biostratigraphy of the Danian/ Selandian transition in the southern Tethys-special reference to the Lowest Occurrence of planktic foraminifera Igorina albeari. Geologica Acta, 7, 6377.

Steurbaut, E. \& Sztrákos, K. 2008. Danian/Selandian boundary criteria and North Sea Basin-Tethys correlations based on calcareous nannofossil and foraminiferal trends in SW France. Marine Micropaleontology, 67, 1-29.

Thomas, E. \& Zachos, J.C. 2000. Was the late Paleocene thermal maximum a unique event? $G F F, \mathbf{1 2 2}, 169-170$.

Tripati, A. \& Elderfield, H. 2005. Deep-sea temperature and circulation changes at the Paleocene-Eocene thermal maximum. Science, 308, 1894-1898.

VAROL, O. 1989. Palaeocene calcareous nannofossil biostratigraphy. In: CruX, J.A. 
\& van Heck, S.E. (eds) Nannofossils and their Applications. Ellis Horwood, London, 267-310.

Westerhold, T., RöHl, U., Raffi, I., ET AL. 2008. Astronomical calibration of the Paleocene time. Palaeogeography, Palaeoclimatology, Palaeoecology, 257, $377-403$.

Yans, J., Strait, S.G., Smith, T., Dupuis, C., Steurbaut, E. \& Gingerich, P.D. 2006. High-resolution carbon isotope stratigraphy and mammalian faunal change at the Paleocene-Eocene boundary in the honeycombs area of the southern Bighorn Basin, Wyoming. American Journal of Science, 306, 712 735 .

Zachos, J., Pagani, M., Sloan, L., Thomas, E. \& Billups, K. 2001. Trends, rhythms, and aberrations in global climate 65 Ma to present. Science, 292, $686-693$.

Zachos, J.C., Wara, M.W., Bohaty, S., ET AL. 2003. A transient rise in tropical sea surface temperature during the Paleocene-Eocene Thermal Maximum. Science, 302, 1551-1554.

Zachos, J.C., RöHl, U., Schellenberg, S.A., ET AL. 2005. Rapid acidification of the ocean during the Paleocene-Eocene thermal maximum. Science, 308, $1611-1615$.

Zachos, J.C., Schouten, S., Bohaty, S., et AL. 2006. Extreme warming of midlatitude coastal ocean during the Paleocene-Eocene Thermal Maximum: Inferences from $\mathrm{TEX}_{86}$ and isotope data. Geology, 34, 737-740.

Received 18 August 2008; revised typescript accepted 26 June 2009.

Scientific editing by Ian Jarvis. 